\title{
PERANCANGAN PENGOLAHAN AIR MINUM TENAGA SURYA KAPASITAS 50 M³/HARI (Dengan Menggunakan Proses Biofiltrasi Dan Ultrafiltrasi)
}

\author{
Design of Solar Powered $50 \mathrm{~m}^{3}$ /Day Drinking Water Treatment \\ (Using Biofiltration-Ultrafiltration Technology) \\ Oleh: \\ Galih Setiaji dan Nusa Idaman Said \\ Pusat Teknologi Lingkungan, BPPT
}

\begin{abstract}
Abstrak
Penyediaan air minum untuk masyarakat mempunyai peranan yang sangat penting dalam peningkatkan kesehatan lingkungan dan masyarakat. Salah satu upaya pemerintah dalam menyediakan pelayanan air minum adalah dengan program penyediaan air minum dan sanitasi berbasis masyarakat. Beberapa kendala pengelolaan air minum berbasis masyarakat antara lain adalah sulitnya pengadaan bahan kimia, serta langkanya sumber energi khusunya untuk daerah yang belum terjangakau oleh jaringan listrik. Pengolahan air minum dengan menggunakan bahan kimia memiliki banyak kekurangan yaitu diantaranya memiliki biaya yang tinggi dan menghasilkan bahan karsinogenik. Pengolahan air minum menggunakan proses biofiltrasi dan ultrafiltrasi merupakan salah satu solusi penggantinya karena memiliki biaya yang lebih murah dan tidak berbahaya. Genset, yang merupakan sumber listrik paling mudah didapat di daerah terpencil, masih dirasa kurang ekonomis. Saat ini telah banyak penelitian yang menunjukkan bahwa untuk daerah terpencil, penggunaan sistem Pembangkit Listrik Tenaga Surya (PLTS) lebih ekonomis dibandingkan dengan menggunakan genset. Maka dari itu dalam tulisan ini telah dibuat perancangan sistem pengolahan air biofiltrasi dan ultrafiltrasi kapasitas $50 \mathrm{~m}^{3} /$ hari dengan tenaga surya. Hasil dari tulisan ini adalah rancangan sistem PLTS yang dapat menyuplai listrik sistem biofiltrasi dan ultrafiltrasi selama 8 jam.
\end{abstract}

Kata Kunci : air minum, tenaga surya, genset, biofiltrasi, ultrafiltrasi.

\begin{abstract}
Drinking water supply for public is big deals for the improvement of environmental and society health. An effort from the government to provide the drinking water supply is to provide a society based of drinking water treatment plant. Some obstacles that have come for the plant in remote areas are the difficulties of getting chemical material for the plant and the lack of energy supply. Drinking water treatment that use chemical materials has a big cost to provide the chemicals. Beside the high cost of treatment, the using of chemicals will harmful the drinking water, because it usually generates such carcinogenic materials. The biofiltration-ultrafiltration treatment is one of the best solutions to replace treatment plant that using chemicals. It has a low cost operation and is more safe than the water treatment that using chemicals. Generator-set (genset), a power generator that easy to get and operate, has uneconomical operation cost. By now, there were many studies proved that in remote areas, the using of Solar Power Plant is more economic than a genset. For those reasons, in this article is designed a solar powered $50 \mathrm{~m}^{3} /$ Day drinking water treatment (biofiltration-ultrafiltration process). The result from the design is the solar power plant that can supply the treatment plant for 8 hours.
\end{abstract}

Keywords: drinking water, solar power, genset, biofiltration, ultrafiltration.

\section{PENDAHULUAN}

\subsection{Latar Belakang}

Penyediaan air minum untuk masyarakat mempunyai peranan yang sangat penting dalam meningkatkan kesehatan lingkungan dan masyarakat. Air minum sangat berperan dalam menurunkan angka penderita penyakit khususnya yang berhubungan dengan air, serta meningkatkan standar atau kualitas hidup masyarakat. Penyediaan air minum untuk masyarakat di Indonesia masih dihadapkan pada 
beberapa permasalahan yang cukup kompleks dan sampai saat ini belum sepenuhnya dapat diatasi. Salah satu masalah yang masih dihadapi sampai saat ini adalah masih rendahnya tingkat pelayanan air bersih untuk masyarakat.

Hal lain yang merupakan tantangan yang dihadapi dalam pembangunan pengolahan air minum adalah menurunnya kuantitas dan kualitas cadangan air baku yang digunakan sebagai sumber air minum. $\mathrm{Hal}$ ini berdampak pada tingginya biaya pengolahan air sehingga masyarakat miskin tidak mampu mengaksesnya.

Berdasarkan UU No. 32 Tahun 2004 tentang Pemerintahan Daerah maka desentralisasi penyelenggaraan sistem penyediaan air minum (SPAM) menjadi kewenangan pemerintah daerah. Pemerintah pusat lebih berperan dalam memfasilitasi/membantu pengembangan SPAM khususnya dalam rangka pengamanan pencapaian sasaran nasional dan pengendalian pelaksanaan standar pelayanan minimal.

Menurut Direktorat Evaluasi Kinerja Pembangunan Sektoral, Bappenas, menyatakan status pencapaian Millenium Development Goals (MDGs) Indonesia menunjukan pada tahun 2009 penduduk dengan akses air minum yang layak (perpipaan dan non perpipaan terlindungi) hanya sebesar $47,3 \%$ dari target tahun 2015 sebesar 60,3\%. Sedangkan akses sanitasi yang layak sudah tercapai $51 \%$ dari target sebesar $62,4 \%$.

Ada dua jalur utama yang saat ini ditempuh pemerintah Indonesia dalam mencapai target MDGs bidang air minum dan sanitasi, yaitu jalur normal dan jalur cepat. Jalur normal adalah dengan meningkatkan cakupan pelayanan maupun kualitas, mulai dari fase perencanaan advokasi, reformasi kebijakan maupun pendanaan dari berbagai sumber. Sumber pendanaan yang bersumber dari hibah maupun program yang sedang berjalan misalnya Percepatan Pembangunan Sanitasi Perkotaan (PPSP), Sanitasi Total Berbasis Masyarakat (STBM), Water Supply and Sanitation Policy and Action Planning (WASPOLA) dan lainnya. Sedangkan program jalur cepat dilakukan dengan cara mempercepat penyediaan air minum dan Sanitasi berbasis masyarakat misalnya program PAMSIMAS, Community Water Supply and Health (CWSH), Pro Air dII.

Di dalam sistem pengelolaan air minum yang berbasis masyarakat pengambilan keputusan atas seluruh aspek yang menyangkut air minum berada di tangan anggota masyarakat. Masyarakat berperan mulai dari tahap awal identifikasi kebutuhan pelayanan air minum, perencanaan tingkat pelayanan yang diinginkan, perencanaan teknis, pelaksanaan pembangunan, hingga ke pengelolaan operasional. Dalam waktu tertentu selama proses perkembangan mereka dapat memperoleh fasilitasi dari pihak luar, misalnya informasi tentang berbagai alternatif teknologi dan bantuan teknis (misalnya kontraktor, pengusaha, atau tenaga profesional), namum keputusan terakhir tetap berada di tangan masyarakat itu sendiri. Salah satu program penyediaan air minum dan sanitasi berbasis masyarakat antara lain adalah PAMSIMAS yang telah dilaksanakan di banyak tempat di Indonesia. Hal ini perlu ditindaklanjuti dengan melakukan replikasi di lokasi-lokasi lain.

Beberapa kendala pengelolaan air minum yang berbasis masyarakat antara lain adalah sulitnya pengadaan bahan kimia, serta langkanya sumber energi khusunya untuk daerah yang belum terjangakau oleh jaringan listrik. Dalam kondisi seperti ini umumnya sumber energi listrik didapatkan dengan mengunakan genset, di mana kendala utama adalah langkanya bahan bakar terutama di daerah pedesaan yang jauh dari kota.

Untuk mengatasi permasalahan tersebut salah satu alternatif proses pengolahan air minum yang dapat digunakan adalah proses pengolahan air minum dengan kombinasi proses biofiltrasi dan ultrafiltrasi tanpa menggunakan bahan kimia. Sedangkan untuk alternatif sumber energinya dirancang menggunakan teknologi pembangkit listrik tenaga surya.

Intensitas radiasi matahari rata-rata di Indonesia sekitar 4,8 kWh/m² (Rahardjo et al 2005). Dengan intensitas tersebut, Indonesia memiliki sumber radiasi yang relativ lebih tinggi jika dibanding dengan negara-negara 4 musim. Saat ini di Indonesia telah banyak produk komponen sistem pembangkit listrik tenaga surya (PLTS) mulai dari modul fotovoltaik, battery, inverter, kontroler, dll.

Telah banyak penelitian ilmiah yang membuktikan bahwa pembangkit listrik tenaga surya lebih handal (Reliabel) dan memiliki kelangsungan hidup (Viability) yang tinggi dibandingkan dengan sumber energi listrik konvensional seperti genset.

Kolhe et al 2002, melakukan penelitian mengenai perbandingan kehandalan secara analisis ekonomi antara sistem Pembangkit Listrik Tenaga Surya (PLTS) Stand-Alone dengan Genset di India. Dalam penelitian tersebut telah dianalisis beberapa biaya yang dibutuhkan untuk ke dua sistem tersebut. Untuk PLTS analisis ekonomi dilakukan pada biaya operasi dan maintenance, dan biaya penggantian baterai, sedangkan untuk sistem genset, analisis ekonomi dilakukan pada biaya konsumsi bahan bakar, pemeliharaan rutin (oli-filter, perawatan mesin, overhaul), dan biaua penggantian generator/mesin saat sudah tidak layak. Dalam penelitian tersebut juga dilakukan perkiraan parameter lain seperti harga modul fotovoltaik yang semakin murah, harga BBM yang cenderung meningkat, umur genset, eskalasi kebutuhan BBM, insolasi matahari, PV array cost, dan kehadandalan system PLTS. Kesimpulan yang didapat dari penelitian tersebut adalah bahwa PLTS memiliki 
biaya yang lebih murah dibandingkan dengan genset meskipun dalam kondisi ekonomi wilayah yang tak baik.

SELF 2008, merupakan organisasi yang bergerak dibidang tenaga surya telah melakukan beberapa penelitian mengenai perbandingan kebutuhan biaya PLTS Stand-Alone dengan Genset di Nigeria, Namibia, dan beberapa negara lain di afrika. Hasil penelitian menunjukkan bahwa sistem PLTS lebih reliable dikarenakan kondisi wilayah yang sangat sulit untuk mendapatkan BBM.

Ahmad et al 2015, melakukan penelitian perbandingan kebutuhan biaya antara genset dengan PLTS sebagai sumber listrik untuk BTS tower. Hasil penelitian menunjukkan bahwa dalam konteks remote area, PLTS lebih unggul dan lebih ekonomis dikarenakan tidak memerlukan biaya perawatan yang besar tidak seperti genset yang memerlukan biaya untuk operator dan biaya BBM harian.

Suryatek, melakukan beberapa studi perhitungan ekonomi mengenai perbandingan kebutuhan biaya sistem PLTS dengan Genset pada daerah terpencil. Dengan memperhitungkan investasi awal, konsumsi bahan bakar, maintenance, dan penggantian komponen, dalam jangka waktu 20 tahun, PLTS 30 kWp memiliki biaya Rp. 1.715.136.187 lebih murah jika dibandingkan dengan Genset 10 kW.

Dengan potensi sumber daya tenaga surya dan permasalahan penyediaan air minum tersebut, maka penting untuk dilakukan pembuatan paket teknologi yang menggabungkan antara teknologi pengolahan air minum dengan teknologi pembangkit listrik tenaga surya (PLTS).

Makalah ini menjelasakan tentang perancangan unit pengolahan air minum dengan proses biofiltrasi dan ultrafiltrasi kapasitas $50 \mathrm{~m}^{3} /$ hari dengan menggunakan sumber energi listrik yang berasal dari tenaga surya.

\section{METODOLOGI}

Metodologi yang digunakan untuk melaksanakan perancangan ini adalah sebagai mana ditunjukkan oleh Gambar 1 berikut :

\begin{tabular}{|c|}
\hline Identifikasi Masalah \\
$\downarrow$ \\
\hline Studi Literatur \\
\hline$\downarrow$ \\
\hline Perancangan Sistem \\
\hline$\downarrow$ \\
\hline Kesimpulan \\
\hline
\end{tabular}

Gambar 1: Metodologi Perancangan Sistem.
- Identifikasi masalah dilakukan dengan studi literatur mengenai permasalahan kebutuhan air bersih dan air minum di daerah pelosok yang tidak terjangkau oleh listrik dari pemerintah.

- Studi literatur pengolahan air dilakukan dengan mempelajari beberapa teknologi pengolahan air menggunakan biofiltrasi dan ultrafiltrasi yang telah ada.

- Studi literatur sistem pembangkit litrik tenaga surya dilakukan dengan mempelajari beberapa sumber literatur (Buku, Jurnal, datasheet) tentang perancangan sistem pembangkit listrik tenaga surya.

- Perancangan sistem dilakukan dengan mendesain kebutuhan sistem pembangkit listrik tenaga surya yang dibutuhkan untuk sebuah sistem pengolahan air minum dengan proses biofiltrasi dan ultrafiltrasi.

- Penggambaran desain dilakukan dengan menggunakan software Microsoft Visio dan SketchUp.

- Simpulan dari perancangan ini adalah rekomendasi sistem dari penulis berdasarkan hasil perancangan yang telah dilakukan.

\section{TINJAUAN PUSTAKA}

\subsection{Teknologi Pengolahan Air Minum Dengan Proses Biofiltasi dan Ultrafiltrasi}

Proses biofitrasi adalah proses pengolahan air baku secara biologis dengan sistem biofilter menggunakan media penyangga untuk menghilangkan polutan organik, amoniak, deterjen, zat besi dan mangan yang ada di dalam air baku. Ultrafiltrasi adalah penyaringan dengan teknologi membran ultrafiltrasi yang dapat menyaring padatan dengan ukuran 0,01mikron. Dengan menggabungkan proses biofiltrasi dengan teknologi membran ultrafiltrasi (UF) maka akan didapatkan suatu alternatif teknologi pengolahan air minum yang dapat menurunkan kandungan zat organik dan amoniak serta partikel tersuspensi tanpa menggunakan bahan kimia seperti pada proses pengolahan air secara konvesional.

\subsubsection{Penghilangan Zat Organik}

Pengolahan air secara biologis merupakan suatau proses penguraian bahan-bahan pencemar baik yang terlarut maupun yang tidak terlarut menjadi bentuk yang lain berupa gas atau padatan (N.J. Hooran 1990). Hasil dari transformasi tersebut dipengaruhi oleh kondisi lingkungan pada saat proses berlangsung yaitu kondisi aerobik dan anaerobik (Said N. I., 2007).

Proses pengolahan biologis secara aerobik merupakan suatu proses yang membutuhkan oksigen untuk menunjang berlangsungnya proses metabolisme 
biokimia oleh bakteri dalam peruraian bahan-bahan organik menjadi bentuk yang lebih sederhana yaitu $\mathrm{CO}_{2}, \mathrm{H}_{2} \mathrm{O}$, senyawa-senyawa oksida seperti nitrat, sulfat, phosphat dan terbentuknya massa sel yang baru (Said N. I., 2007). Efektivitas penyisihan zat organik secara biologi tergantung dari jumlah oksigen terlarut, jenis mikroorganisme dan jumlah zat pengurai (Said N. I., 2002). Adanya $\mathrm{O}_{2}$ menyebabkan proses oksidasi aerob dapat berlangsung, bahan bahan organik akan dirubah menjadi produk - produk akhir yang relatif stabil dan sisanya akan disintesis menjadi mikroba baru. Secara umum dapat dilihat pada persamaan 1 berikut ini.

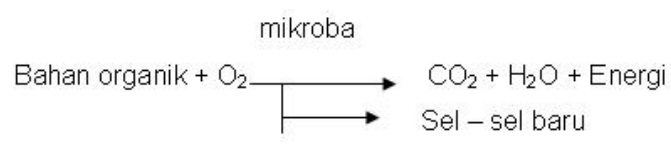

Sedangkan proses pengolahan biologis secara anaerob secara garis besar adalah konversi bahan organik atau organik karbon menjadi gas bio atau gas methan dan karbondioksida. Proses konversi tersebut meliputi tiga tahap yaitu: hidrolisis dan fermentasi; Asetogenesis; Metanogenesis. Hidrolisis dan fermentasi adalah penguraian polimer-polimer organik tak larut menjadi senyawa organik terlarut misalnya protein dihidrolisis menjadi asam amino yang selanjutnya menjadi asam keto. Asetogenesis merupakan tahapan pembentukan asam asetat. Metanogenesis merupakan tahapan pembentukan gas metana dari asam asetat.

\subsubsection{Penghilangan Amonia}

Di dalam proses biofiltrasi, senyawa amoniak akan diubah menjadai nitrit, kemudaian senyawa nitrit akan diubah menjadi nitrat. Mekanisme proses penguraian senyawa amoniak yang terjadi pada lapisan biofilm secara sederhana dapat diilustrasikan seperti pada Gambar 2.

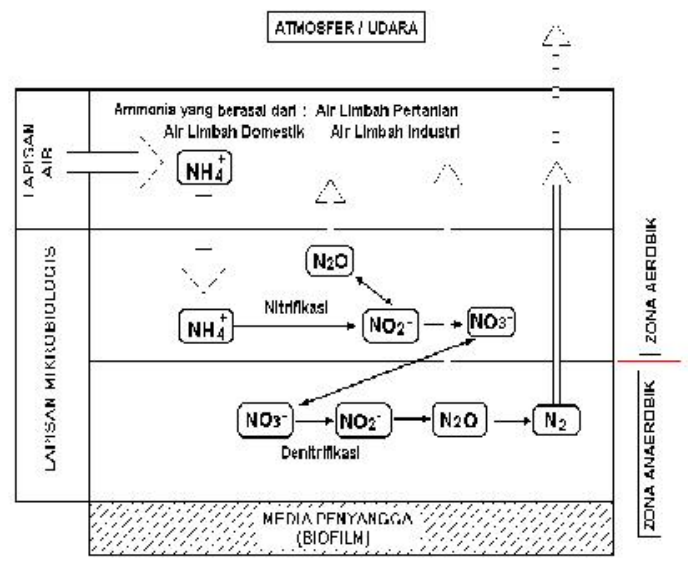

Gambar 2: Ilustrasi Dari Mekanisme Proses Penguraian Amoniak Di Dalam Biofilm. (Said Nusa I., 2007)
Lapisan terluar media penyangga adalah lapisan tipis zona aerobik, senyawa amoniak dioksidasi dan diubah ke dalam bentuk nitrit. Sebagian senyawa nitrit diubah menjadi gas dinitrogen oksida $\left(\mathrm{N}_{2} \mathrm{O}\right)$ dan sebagian lain diubah menjadi nitrat. Proses yang terjadi tersebut dinamakan proses nitrifikasi.

Semakin lama lapisan biofilm yang tumbuh pada media penyangga tersebut, maka semakin tebal lapisan biofilm sehingga menyebabkan oksigen tidak dapat masuk ke dalam lapisan biofilm sehingga mengakibatkan terbentuknya zona anaerobik. Pada zona anaerobik ini, senyawa nitrat yang terbentuk diubah ke dalam bentuk nitrit yang kemudian dilepaskan menjadi gas nitrogen $\left(\mathrm{N}_{2}\right)$. Proses demikian tersebut dinamakan proses denitrifikasi.

\subsubsection{Reaktor Biologis Unggun Tetap (Fixed Bed Biofilter)}

Reaktor Biologis Unggun Tetap adalah Struktur reaktor biofilter menyerupai saringan (filter) yang terdiri atas susunan atau tumpukan bahan penyangga yang disebut dengan media penyangga yang disusun baik secara teratur maupun acak di dalam suatu bejana. Fungsi media penyangga adalah sebagai tempat tumbuh dan berkembangnya mikroorganisme yang akan melapisi permukaan media membentuk lapisan massa yang tipis (biofilm). Mikroorganisme ini menguraikan bahan organik yang ada dalam air. Air yang diolah akan dikontakkan dengan sejumlah mikroba dalam bentuk lapisan film (slime) yang melekat pada permukaan media.

Media penyangga merupakan salah satu kunci pada proses biofilter. Efektifitas dari suatu media tergantung pada :

- Luas permukaan, semakin luas permukaan media maka semakin besar jumlah biomassa per unit volume.

- Volume rongga, semakin besar volume rongga/ruang kosong maka semakin besar kontak antara substrat dalam air buangan dengan biomassa yang menempel

Faktor terpenting yang mempengaruhi pertumbuhan bakteri pada media penyangga adalah kecepatan aliran serta bentuk dan jenis konfigurasi media. Media yang digunakan dapat berupa kerikil, batu pecah (split), media plastik (polivinil chlorida), dan partikel karbon aktif dan lainnya. Media yang sering digunakan pada proses biologis khususnya biofiter adalah media plastik yang terbuat dari PVC (Gabriel Bitton, 1994). Kelebihan dalam penggunaan media plastik ini antara lain :

- Ringan serta mempunyai luas permukaan spesifik besar (luas permukaan per satuan volume) berkisar antara sebesar $85-226 \mathrm{~m} 2 / \mathrm{m} 3$. 
- Volume rongga yang besar dibanding media lainnya (hingga 95\%) sehingga resiko kebuntuan kecil.

\subsubsection{Teknologi Membran}

Teknologi membran sebenarnya bukanlah suatu teknologi yang baru ditemukan, karena membran itu sendiri telah digunakan lebih dari 50 tahun yang lalu. Adapun jenis membran yang tersedia saat ini dibagi menjadi 4 kelompok besar yang dikelompokkan berdasarkan ukuran tingkat penyaringannya atau sering disebut dengan istilah "Filtration degree".

Tingkat-tingkat penyaringan yang dimaksud adalah sebagai berikut :

- Micro Filtration (MF)

- Ultra Filtration (UF)

- Nano Filtration (NF)

- Hyper Filtration / Reverse Osmosis (RO)

Distribusi ukuran partikel yang dapat dipisahkan sesuai dengan tingkatan proses filtrasi dapat dilihat pada Gambar 3.

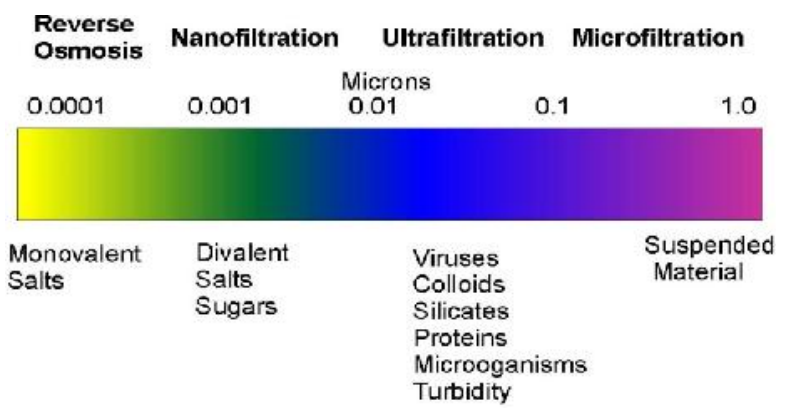

Gambar 3: Distribusi Ukuran Partikel Yang Dapat Dipisahkan Sesuai Dengan Tingkatan Proses Filtrasi.

Dalam penelitian ini, membran yang digunakan adalah membran ultrafiltrasi. Diharapkan dengan menggunakan membran ultrafiltrasi ini partikel seperti virus, koloid, dan mikroorganisme dapat tersaring sehingga akan menghasilkan air minum yang berkualitas baik.

\subsection{Paket Teknologi Pengolahan Air Dengan Proses Biofiltrasi dan Ultrafiltrasi}

Salah satu paket teknologi pengolahan air dengan proses biofiltrasi dan ultrafiltrasi adalah sebagaimana ditunjukkan pada Gambar 4. Paket teknologi tersebut merupakan paket teknologi pengolahan air minum dengan kapasitas $180 \mathrm{~m}^{3} /$ hari (Said Nusa I. et al, 2007). Air baku dari saluran intake dipompa ke reaktor biofilter dengan menggunakan pompa air baku. Sebelum menuju reaktor, air baku di dalam pipa dicampur dengan udara menggunakan pipa venturi. Reaktor biofilter diisi dengan media biofilter dari bahan plastik tipe sarang tawon. Di dalam reaktor biofilter tersebut senyawa polutan misalnya zat organik, amoniak, zat besi , mangan, deterjen dan senyawa polutan lain dapat diuraikan secara biologis. Selain itu padatan tersuspensi yang ada di dalam air baku dapat diendapakan. Air yang keluar dari biofilter selanjutnya di tampung ke bak penampung, kemudian dipompa ke filter automatik yang dapat menyaring kontoran sampai 10-50 mikron. Dari filter automatik air dilairkan ke unit ultrafiltrasi yang dapat menyaring sampai ukuran 0,01 mikron.

Unit ultrafiltrasi menggunakan modul membrane tipe hollow fiber. Selanjutnya air yang keluar dari unit ultrafiltrasi dilairkan ke bak penampung air olahan sambil diinjeksi dengan larurtan kaporit untuk proses disinfeksi dan selanjutnya dilairkan ke sistem distribusi.

Sistem biofiltrasi-ultrafiltrasi tersebut dapat menghilangkan kadar organik dengan efisiensi 71,08 \% pada waktu tinggal 3 jam, sedangkan efisiensi penghilangan amoniak adalah sebesar 83,26 \% pada waktu tinggal 3 jam (Said Nusa I. et al, 2007), dan sistem ultrafiltrasi tersebut sangat handal dalam menghilangkan kekeruhan air dengan ukuran hingga 0,01 mikron.

Beberapa kelebihan paket sistem kombinasi biofiltrasi dan ultrafiltrasi antara lain adalah :

- Penggunaan proses biofiltrasi dapat menghilangkan senyawa polutan yang tidak bisa dihilangkan dengan proses konvensional misalnya, zat organik, amoniak, deterjen, pestisida, dll. Senyawa tersebut dapat diuraikan dengan proses biologis secara alami (natural).

- Tanpa menggunakan bahan koagulan dan flokulan. Dalam hal ini bahan yang digunakan hanya larutan kaporit untuk mendapatkan konsentrasi sisa klor yang cukup agar tidak terjadi rekontaminasi.

- Dengan proses ultrafiltrasi dapat dihasilkan air olahan dengan kualitas yang sangat baik dan stabil.

- $\quad$ Bentuknya lebih kompak sehingga luas area yang dibutuhkan lebih kecil.

- $\quad$ Sangat fleksibel jika ada penambahan kapasitas.

- Dapat dioperasikan dengan sederhana dan handal, manual flushing dilakukan sesuai kebutuhan dengan indikator pressure gauge.

- Biaya investasi yang murah. 
Spesifikasi teknis dari sistem tersebut adalah sebagai Berikut:

- Pompa Biofiltrasi

$\begin{array}{ll}\text { Tipe } & =\text { Submersible } \\ \text { Kapasitas } & =0,1-0,22 \mathrm{~m}^{3} / \text { menit } \\ \text { Bahan } & =\text { Polimer atau Stainless steel } \\ \text { Total Head } & =8-11,5 \mathrm{~m} \\ \text { Diamter Outlet } & =2 "\end{array}$

- $\quad$ Reaktor Biofiltrasi

$\begin{array}{ll}\text { Material } & =\text { Figerglass (FRP) } \\ \text { Volume } & =9000 \text { liter } \\ \text { Waktu Tinggal } & =2-3 \text { jam } \\ \text { Dimensi Bak } & =150 \mathrm{~cm} \times 300 \mathrm{~cm} \times 220 \mathrm{~cm} \\ \text { Perlengkapan: } & =\text { Bak penenang, ruang lumpur dan } \\ \text { kran penguras lumpur. }\end{array}$

- Pipa Venturi

Diameter = 2 “

- Media Sarang Tawon

$\begin{array}{ll}\text { Material } & =\text { PVC } \\ \text { Ketebalan } & =0,15-0,23 \mathrm{~mm} \\ \text { Luas Kontak Spesifik } & =150-200 \mathrm{~m} 2 / \mathrm{m3} \\ \text { Diameter Lubang } & =3 \mathrm{~cm} \times 3 \mathrm{~cm} \\ \text { Porositas Rongga } & =0,98 \\ \text { Volume Media } & =3,24 \mathrm{~m}^{3}\end{array}$

- Bak Penampung Antara

$\begin{array}{ll}\text { Volume } & =5000 \text { liter } \\ \text { Bahan } & =\text { Polyethylene } \\ \text { Kapasitas } & =0,1-0,22 \mathrm{~m}^{3} / \text { menit }\end{array}$

- Pompa Feed Ultrafiltrasi

$\begin{array}{ll}\text { Kapasitas } & =100-120 \text { liter per menit } \\ \text { Bahan } & =\text { Stainless steel } \\ \text { Head } & =30 \mathrm{~m}\end{array}$

- Mikro Strainer

$\begin{array}{ll}\text { Diameter } & =8^{\prime \prime} \\ \text { Tinggi } & =60 \mathrm{~cm} \\ \text { Kapasitas } & =6-8 \mathrm{~m}^{3} \text { per jam } \\ \text { Fitration Degre } & =75 \text { micron }\end{array}$

Bahan

$$
=\text { Stainless Steel }
$$

- Unit Ultrafiltrasi

$\begin{array}{ll}\text { Membran } & =\text { Hollow Fiber } \\ \text { Material } & =\text { Hydrophilic Modified PAN } \\ \text { Housing } & =\text { Stainless Steel } \\ \text { Dimensi } & =\text { Dia. } 4 " \text { Panjang } 40^{\prime \prime} \\ & =0.10-0.01 \text { micron } \\ \text { Derajat Filtrasi } & =10 \text { unit } \\ \text { Jumlah Membrane } & =\text { Otomatis } \\ \text { Backwash } & =4 \text { Solenoid Valve } \\ \text { Aksesoris } & =\text { Carbon Steel } \\ \text { Skeed } & =140-180 \mathrm{~m}^{3} \text { per hari } \\ \text { Kapasitas Total } & \end{array}$

- $\quad$ Pompa Feed Ultrafiltrasi

$\begin{array}{ll}\text { Kapasitas } & =100-120 \text { liter per menit } \\ \text { Bahan } & =\text { Stainless steel } \\ \text { Head } & =30 \mathrm{~m}\end{array}$

- $\quad$ Pompa Dosing

$\begin{array}{ll}\text { Tekanan } & =7 \mathrm{Bar} \\ \text { Kapasitas } & =4,7 \mathrm{I} / \mathrm{jam} \\ \text { Diafragma } & =\text { Hypalon }\end{array}$

- $\quad$ Tangki Kimia

$\begin{array}{ll}\text { Volume } & =50 \text { liter } \\ \text { Dimensi } & =\text { Dia. } 50 \mathrm{~cm}, \text { Tinggi } 60 \mathrm{~cm} \\ \text { Material } & =\text { Polyethylene }\end{array}$

- Tangki Penampung

$\begin{array}{ll}\text { Volume } & =5000 \text { liter } \\ \text { Bahan } & =\text { Polyethylene }\end{array}$

- Rangka

Bahan $=$ Stainless Steel dan Alumunium

- Panel Kelistrikan

Box Panel= Mildsteel - Outdoor

Aksesoris= Conductivity Meter, Alarm System, Selector Switch.

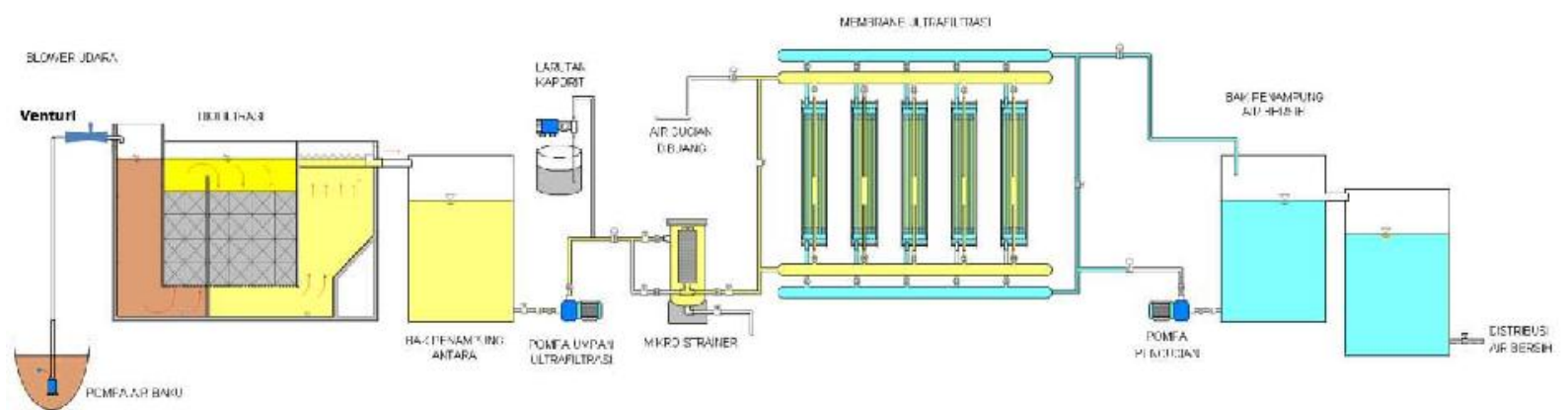

Gambar 4: Ilustrasi Proses Pengolahan Air Minum dengan Kombinasi Proses Biofilter dan Ultrafiltrasi. (Said Nusa I., 2009) 


\subsection{Teknologi Pembangkit Listrik Tenaga Surya (PLTS)}

\subsubsection{Komponen-Komponen Utama PLTS}

- $\quad$ Fotovoltaik (Photovoltaic)

Secara harfiah fotovoltaik mempunyai arti cahaya-listrik yang berarti proses konversi energi cahaya menjadi energi listrik yang dilakukan oleh sel fotovoltaik, penemunya adalah Edmond Becquerel dan kawan-kawan pada abad ke-18. Prinsip kerja sel fotovoltaik silikon adalah berdasarkan konsep semikonduktor $\mathrm{p}$-n junction seperti ditunjukkan pada Gambar 5. Ketika foton mengenai sel fotovoltaik reaksi yang dihasilkan adalah adanya pemisahan elektron yang menuju ke salah satu lapisan sel sehingga terbentuklah arus / tegangan pada sel fotovoltaik.

Daya yang dihasilkan modul fotovoltaik adalah sama dengan hasil kali arus dan tegangan yang dihasilkan oleh modul fotovoltaik:

$$
P_{\max }=V_{m} x I_{m}
$$

Keterangan:

$$
\begin{array}{ll}
\mathrm{Vm} & =\text { tegangan maksimum (Volt) } \\
\mathrm{Im} & =\text { arus maksimum (Ampere) } \\
\mathrm{Pmax} & =\text { daya maksimum (Watt) }
\end{array}
$$

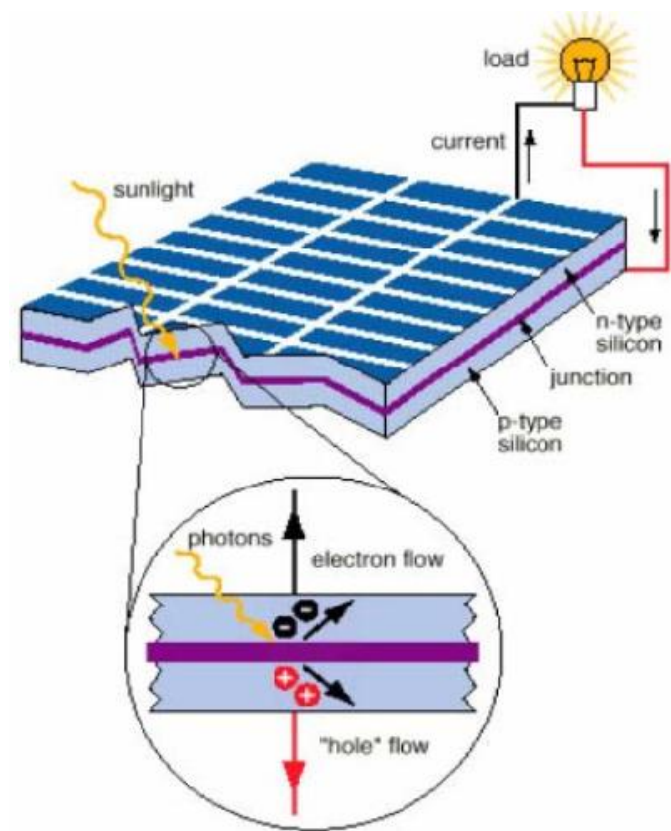

Gambar 5: Konversi Cahaya Matahari Menjadi Listrik. (PPPPTK, 2008)

Saat ini telah berkembang beberapa modul fotovoltaik yaitu: Monokristal, Polikristal, Edge Defined Film Growth Ribbon (EFG), dan Thin Film. Modul Monokristal (Gambar 6.a) memiliki kemurnian material silikon yang sangat tinggi yakni 99,99 \%.
Modul monokristal ini mempunyai efisiensi konversi yang cukup tinggi yakni $16-17 \%$, bahkan silikon sel fotovoltaik produksi "SunPower" mempunyai efisiensi hingga 20\% (Yuliarto, 2006). Modul Polikristal (Gambar 6.b) dibuat dengan material campuran dan memiliki efisiensi yang lebih rendah jika dibandingkan dengan Modul Monokristal yakni sebesar 12-14\%. Modul EFG (Gambar 6.c) merupakan modul yang pembuatanya menggunakan metode penumbuhan "wafer" monokristal seperti pita langsung dari cairan silikon dengan menggunakan pita kapiler yang dapat menghasilkan sel dengan lebar 5-10 cm. Modul EFG ini memiliki efisiensi konversi sebesar $13 \%$. Modul Thin Film (Gambar 6.d) memiliki bentuk yang tipis dan lentur dengan efisiensi konversi hingga 19,5\%. Modul ini dibuat dengan mencampur material silikon dengan bahan kadmium tellurida ( $\mathrm{CdTe}$ ) dan tembaga indium galium selenida (CIGS).

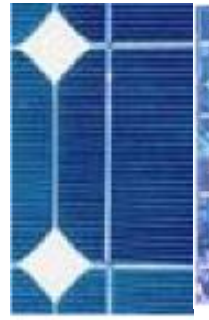

a)

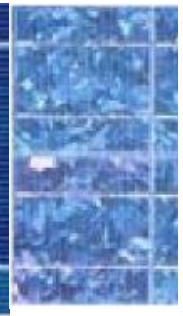

b)

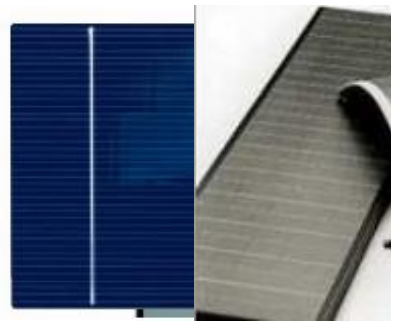

c) d)
Gambar 6: Beberapa Jenis Modul Fotovoltaik. (PPPPTK, 2008)

- $\quad$ Baterai (Battery)

Salah satu komponen yang cukup penting dalam sistem Pembangkit Listrik Tenaga Surya (PLTS) adalah komponen baterai. Komponen ini merupakan jantung sistem untuk bekerja setiap saat sebagai penyimpan energi dari fotovoltaik.

Baterai menyimpan energi listrik yang dihasilkan modul fotovoltaik pada saat matahari bersinar, dan baterai akan mengeluarkan kembali energi listrik pada saat modul fotovoltaik tidak dapat lagi menghasilkan energi listrik. Pada kondisi normal baterai dipergunakan saat malam hari atau saat cuaca berawan, akan tetapi jika terjadi kondisi beban yang berlebih pada siang hari, baterai dapat dipergunakan menambah beban yang dihasilkan modul surya.

Baterai yang digunakan dalam sistem PLTS merupakan baterai jenis "Deep Cycle" yaitu baterai yang dibuat dengan pelat lebih tebal yang memungkinkan untuk melepaskan energi listrik dalam selang waktu yang panjang. Semakin tebal pelat baterai semakin panjang usia baterai yang diharapkan. Baterai deep cycle dirancang untuk dapat melakukan pelepasan (discharge) sampai dengan $80 \%$ DOD (Deep of Discharge) dari kapasitas total pada tiap siklusnya. 
Gambar 7 menunjukkan grafik jumlah siklus (number of cycle) baterasi vs $D O D$ baterai. Semakin besar ratarata $D O D$ baterai maka semakin sedikit siklus baterai tersebut. Artinya jika rata-rata $D O D$ baterai adalah $80 \%$ maka siklus baterai (berdasarkan grafik Gambar 7) hanya berjumlah kurang dari 2000 siklus.

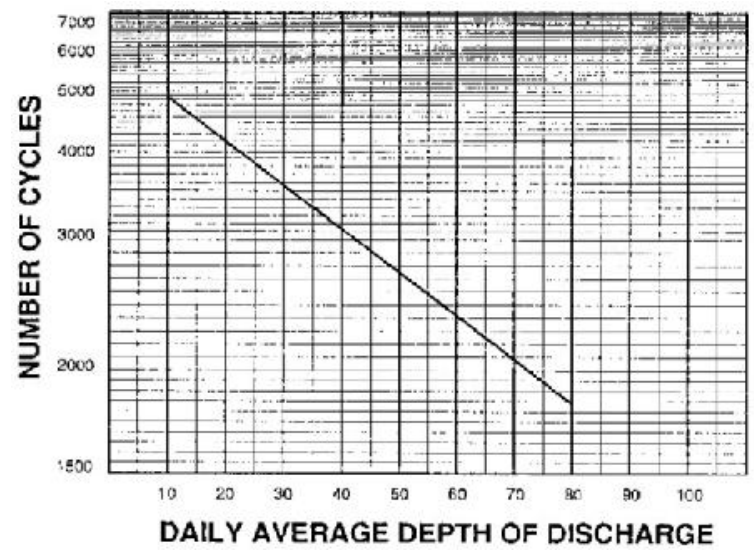

Gambar 7: Grafik Jumlah Siklus (number of cycle) Baterai VS DOD Baterai. (PPPPTK, 2008)

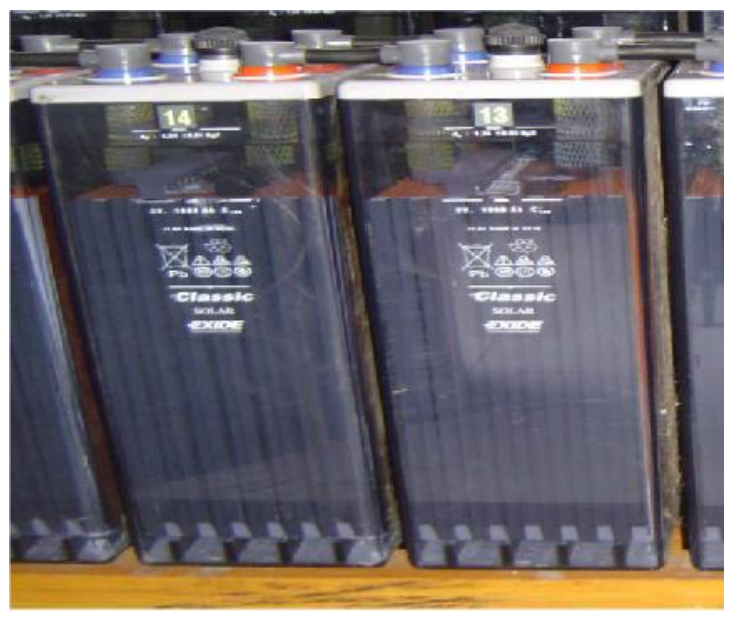

Gambar 8: Baterai Deep Cycle. (PPPPTK, 2008)

\section{- Battery Charger Regulator}

BCR (Battery Charge Regulator) mempunyai beberapa istilah lain diantaranya BCU (Battery Control Unit) dan SCC (Solar Charge Controller). BCR merupakan piranti charger baterai dengan sumber atau input untuk pengisian baterainya berasal dari modul fotovoltaik. Alat ini biasanya juga dilengkapi dengan hardware untuk manajemen energi, inverter, dan beberapa fungsi lain seperti proteksi sistem, indikator dan bahkan terdapat pencatat data sistem. Beberapa fungsi penting BCR adalah sebagai berikut :
- $\quad$ Mengatur transfer energi dari modul PV $\rightarrow$ baterai $\rightarrow$ beban, secara efisien dan semaksimal mungkin;

- Mencegah baterai dari overcharge dan underdischarge;

- Membatasi daerah tegangan kerja baterai;

- Menjaga / memperpanjang umur baterai;

- Mencegah beban berlebih dan hubung singkat;

- Menghindari dari kesalahan polaritas terbalik;

- Memberikan informasi kondisi sistem pada pemakai.

Pemilihan BCR dilakukan berdasarkan kebutuhan tegangan kerja dan arus maksimal sistem. Tegangan kerja sistem pada umumnya adalah $12 \mathrm{~V}, 24$ $\mathrm{V}$, atau $48 \mathrm{~V}$. Sedangkan untuk parameter arus, arus maksimal BCR harus berada di atas arus maksimal sistem. (P. Irawan, 2011)

- Inverter

Inverter berfungsi untuk mengubah tegangan direct-current (DC) menjadi tegangan alternating current (AC) berupa sinyal sinus setelah melalui rangkaian pembentuk gelombang dan rangkaian filter. Tegangan output yang dihasilkan harus stabil baik amplitudo maupun frekuensi, memiliki distorsi yang rendah, dan tidak terdapat tegangan transien. Gambar 9 berikut ini adalah contoh sistem quasi-square wave inverter. Sistem ini dapat menghasilkan sinyal dengan duty-cycle yang bervariasi dengan menggunakan rangkaian paralel LC.

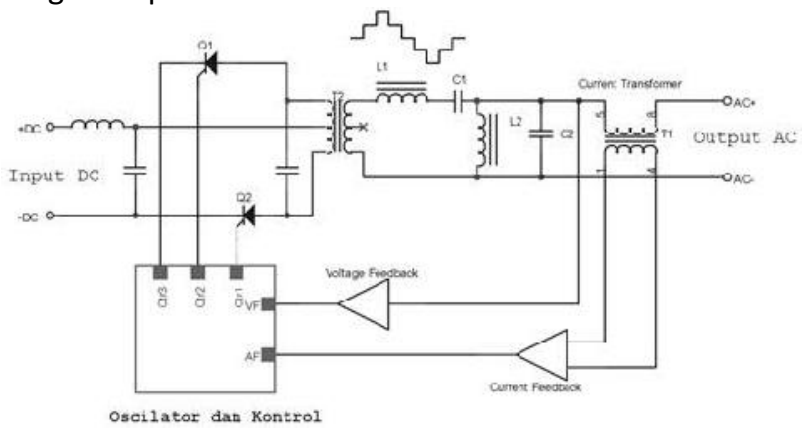

Gambar 9: Rangkaian Inverter Dengan Tipe Quasi-

Square Wave. (PPPPTK, 2008)

Tipe inverter quasi-square tidak cocok untuk digunakan jika beban berupa motor listrik atau peralatan elektromekanik. Untuk peraltan seperti motor listrik sebaiknya menggunakan inverter yang menghasilkan gelombang sinus murni (Pure Sine Wave Inverter). 


\subsubsection{Dasar Perancangan PLTS}

\section{- $\quad$ Beban Sistem}

Penentuan kebutuhan beban yang akan disuplai merupakan langkah awal dalam merancang sistem Pembangkit Listrik Tenaga Surya (PLTS). Jumlah energi harian yang dibutuhkan oleh sebuah beban dihitung dengan menggunaan Persamaan (3).

$$
W=P x t
$$

Keterangan :

$\mathrm{W}$ = energi harian (Wh)

$\mathrm{P} \quad=$ daya beban $(\mathrm{W})$

$\mathrm{t} \quad=$ lama penggunaan per hari $(\mathrm{h})$

\section{- $\quad$ Kapasitas Daya Modul Fotovoltaik}

Kapasitas daya modul fotovoltaik dapat dihitung dengan memperhatikan faktor - faktor kebutuhan energi dari sistem yang disyaratkan, faktor penyesuaian (adjustment factor), dan insolasi matahari. Faktor penyesuaian pada sebagian besar instalasi PLTS adalah 1,1 (Mark Hankins, 1991 Small Solar Electric System for Africa). Data insolasi matahari dapat diperoleh dari Badan Meteorologi Klimatologi dan Geofisika (BMKG) atau dari satelit NASA secara online. Besarnya kapasitas daya modul fotovoltaik dihitung dengan Persamaan (4).

$$
\text { Kapasitas Daya Modul } P V=\frac{\mathrm{w}_{\mathrm{T}}}{\text { Insolasi Matahari }} x \text { faktor penyesuaian }(4)
$$

Keterangan :

$\mathrm{WT}=$ Total energi dari sistem yang disyaratkan (Wh)

\section{- $\quad$ Kapasitas Baterai}

Untuk mendapatkan besarnya kapasitas baterai yang dibutuhkan oleh sistem, maka satuan energi Watt-hours (Wh) terlebih dahulu dikonversikan menjadi satuan Ampere-hours (Ah) sesuai dengan satuan kapasitas baterai. Perhitungan konversi tersebut dapat dihitung menggunakan Persamaan (5).

$$
\mathrm{Ah}=\frac{\mathrm{W}_{\mathrm{T}}}{\mathrm{V}_{\mathrm{S}}}
$$

Keterangan :

$\mathrm{Ah}=$ kapasitas penyimapanan (Ah)

$\mathrm{W}_{\mathrm{T}}=$ beban maksimum (W)

$\mathrm{V}_{\mathrm{S}} \quad$ = tegangan kerja sistem (V)

Hari otonomi yang ditentukan dalam perancangan ini adalah 1 hari, sehingga baterai hanya akan menyimpan energi dan menyalurkan energi tersebut pada hari itu juga. Nilai dari Deep of
Discharge (DOD) pada baterai adalah 80 \% (Liem dkk, 2008). Besarnya kapasitas baterai yang dibutuhkan oleh sistem dapat dihitung menggunakan Persamaan (6).

$$
C_{B}=\frac{A h \times d}{D O D}
$$

Keterangan :

$\mathrm{C}_{\mathrm{B}}=$ kapasitas baterai yang dibutuhkan sistem (Ah)

Ah = kapasitas baterai (Ah)

$\mathrm{d} \quad=$ harga otonomi (hari)

DOD = Deep of Discharge atau kapasitas aki yang terpakai (\%)

\section{- Ukuran BCR}

Kapasitas maksimal arus yang akan mengalir melalui Battery Charge Regulator (BCR) dapat ditentukan dengan mengetahui besarnya beban maksimum yang akan disuplai. Kapasitas arus maksimum BCR dapat dihitung dengan Persamaan (7).

$$
\mathrm{I}_{\mathrm{m}}=\frac{\mathrm{P}_{\mathrm{m}}}{\mathrm{v}_{\mathrm{S}}}
$$

Keterangan :

$$
\begin{array}{ll}
\mathrm{Im}_{\mathrm{m}} & =\text { kapasitas arus maksimum BCR }(\mathrm{A}) \\
\mathrm{P}_{\mathrm{m}} & =\text { beban maksimum }(\mathrm{W}) \\
\mathrm{V}_{\mathrm{S}} & =\text { tegangan kerja sistem }(\mathrm{V})
\end{array}
$$

\section{HASIL DAN PEMBAHASAN}

Berdasarkan spesifikasi paket teknologi biofiltrasi dan ultrafiltrasi yang telah ada, untuk mendapatkan kapasitas sebesar $50 \mathrm{~m}^{3} /$ hari sistem harus beroprasi selama 8 jam. Tabel 1 berikut ini menunjukkan perhitungan kebutuhan energi untuk dapat mengoperasikan keseluruhan sistem selama 8 jam. Data kebutuhan daya peralatan didapatkan dari datasheet produk yang sesuai dengan spesifikasinya.

Tabel 1: Kebutuhan Daya dan Energi Masing-masing Komponen.

\begin{tabular}{|l|l|c|c|}
\hline No & Nama Peralatan & $\begin{array}{c}\text { Kebutuhan } \\
\text { Daya (watt) }\end{array}$ & $\begin{array}{c}\text { Kebutuhan } \\
\text { Energi (kWh) } \\
\text { 8 Jam }\end{array}$ \\
\hline 1 & $\begin{array}{l}\text { Pompa Air Baku } \\
\text { Biofiltrasi }\end{array}$ & 500 & 4 \\
\hline 2 & $\begin{array}{l}\text { Pompa } \\
\text { Umpan/Backwash } \\
\text { Ultrafiltrasi }\end{array}$ & 500 & 4 \\
\hline 3 & Pompa Distribusi & 100 & 0,8 \\
\hline 4 & Pompa Dosing & 100 & 0,8 \\
\hline & Jumlah & $\mathbf{1 2 0 0}$ & $\mathbf{9 , 6}$ \\
\hline
\end{tabular}


Gambar 10 memperlihatkan peta durasi penyinaran optimum per hari di wilayah indonesia. Dari peta tersebut terlihat bahwa rata-rata durasi penyinaran optimum untuk wilayah indonesia adalah 4 -5 jam.

Durasi penyinaran matahari yang diambil pada penelitian ini adalah yang paling minimum yakni 4 jam agar menjamin sistem dapat diterapkan di seluruh wilayah Indonesia. Dengan faktor penyesuaian sebesar 1,1 (satu koma satu), total kebutuhan energi sebesar $9.600 \mathrm{Wh}$, dan insolasi matahari 4 jam maka didapatkan kebutuhan fotovoltaik sebesar $2640 \mathrm{Wp}$ dengan pembulatan ke atas, agar panel surya menjadi genap seperti sistem PLTS pada umumnya maka didapatkan nilai 3000 Wp.

Tegangan kerja yang digunakan untuk menentukan kebutuhan kapasitas penyimpanan (Ah) pada sistem ini adalah tegangan baterai pada umumnya yakni $12 \mathrm{~V}$. Dengan kebutuhan daya sebesar 9.600 Wh maka dengan menggunakan Persamaan 5, kebutuhan kapasitas penyimpanan adalah $800 \mathrm{Ah}$. Dengan menggunakan Persamaan 6, berdasarkan asumsi hari otonomi adalah 1 (satu) hari dan menggunakan baterai Deep Cycle dengan DOD 80\% diperoleh kapasitas baterai yang akan digunakan adalah Sebesar 1000 Ah.

Ukuran arus BCR tergantung dari tegangan kerja dan daya maksimal sistem. Umumnya tegangan kerja sebuah sistem PLTS adalah $12 \mathrm{~V}, 24 \mathrm{~V}$, dan $48 \mathrm{~V}$. Dengan daya maksimal fotovoltaik sebesar $3000 \mathrm{Wp}$ maka dengan menggunakan Persamaan 7 , ukuran arus dapat dihitung secara berturut-turut sebesar $250 \mathrm{~A}$ (12 V), $125 \mathrm{~A}(24 \mathrm{~V}), 62,5 \mathrm{~A}(48 \mathrm{~V})$. BCR yang digunakan tidak serta merta harus berkapasitas sama dengan kebutuhan arus tersebut. Kebutuhan arus tersebut dapat dibagi dengan beberapa BCR dengan kapasitas arus di bawahnya.

\subsubsection{Rekomendasi Desain PLTS}

Modul fotovoltaik dipilih berdasarkan beberapa pertimbangan, yakni dimensi dan berat modul. Referensi dimensi dan berat modul diambil dari sebuah produsen fotovoltaik yakni GREENTEK INDIA PVT. LTD. Berdasarkan pengalaman penulis dan berdasarkan perhitungan teknis, modul fotovoltaik yang dipilih adalah modul dengan daya $150 \mathbf{~ W p}$. Hal teknis yang dipertimbangkan adalah jumlah modul yang lebih sedikit dan luas lahan bangunan yang lebih kecil dibandingkan dengan ukuran modul di bawahnya sehingga konstruksi instalasi dan pemasangan pengkabelan lebih mudah. Jumlah modul $150 \mathrm{Wp}$ untuk mendapatkan daya sebesar $3000 \mathrm{Wp}$ adalah 20 modul dengan total luas $19,3 \mathrm{~m} 2$ sedangkan untuk ukuran-ukuran di bawahnya yaitu $100 \mathrm{Wp}$ dan $50 \mathrm{Wp}$ adalah secara berturut-turut sebanyak 30 dengan total luas $20,7 \mathrm{~m} 2$ dan 60 modul dengan total luas $30,4 \mathrm{~m} 2$.
Tabel 2 berikut ini menunjukkan perbandingan dimensi dan berat untuk modul fotovoltaik dengan ukuran $150 \mathrm{Wp}, 100 \mathrm{Wp}$, dan $50 \mathrm{Wp}$.

Tabel 2: Perbandingan Dimensi dan Berat Modul Surya. (Greentek 2007)

\begin{tabular}{|c|c|c|}
\hline $\begin{array}{c}\text { Ukuran Daya } \\
(\mathrm{Wp})\end{array}$ & $\begin{array}{c}\text { Dimensi (Panjang x } \\
\text { Lebar) }\end{array}$ & $\begin{array}{c}\text { Berat } \\
(\mathrm{kg})\end{array}$ \\
\hline 150 & $1475 \mathrm{~mm} \times 655 \mathrm{~mm}$ & 12 \\
\hline 100 & $1055 \mathrm{~mm} \times 655 \mathrm{~mm}$ & 7.4 \\
\hline 50 & $775 \mathrm{~mm} \times 655 \mathrm{~mm}$ & 6.5 \\
\hline
\end{tabular}

Gambar 11 merupakan desain elektrikal modul fotovoltaik daya $3000 \mathrm{Wp}$ dengan tegangan kerja 24 V. Konfigurasi pemasangan modul yang dipakai adalah kombinasi antara seri dan paralel. Dari 20 fotovoltaik dibagi menjadi 5 sub bagian yaitu masing-masing adalah 4 fotovoltaik. Bagian tersebut terdiri dari 2 buah fotovoltaik yang dipasang paralalel, selanjutnya pasangan tersebut dipasang seri dengan 2 buah fotovoltaik sisanya yang juga telah dipasang paralel sehingga menghasilkan tegangan 24 volt dengan arus sebesar 25 A. Selanjutnya energi yang dihasilkan disalurkan menggunakan BCR berukuran 30 A. Selanjutnya kelima sub bagian tersebut dipasang paralel untuk mengisi baterai dengan tegangan kerja 24 V. Pemilihan BCR 30 A adalah dikarenakan ketersediaan produk BCR yang banyak dijumpai di pasaran di indonesia adalah berukuran 5-30 A. Untuk BCR dengan ukuran 50 A ke atas biasanya digunakan untuk PLTS yang lebih besar dan memiliki fitur-fitur I-O kontrol jaringan ethernet dalam pengoperasianya. Battery Charger Regulator yang digunakan adalah tipe PWM. Produk BCR umumnya dapat bekerja secara otomatis pada tegangan $12 \mathrm{~V}$ dan $24 \mathrm{~V}$. Produk $B C R$ tipe PWM umumnya berukuran $10 \mathrm{~A}, 15 \mathrm{~A}, 20 \mathrm{~A}, 30 \mathrm{~A}$, 35 A, 40 A, dan 60 A (Steca, 2016)(Schneider, 2015).

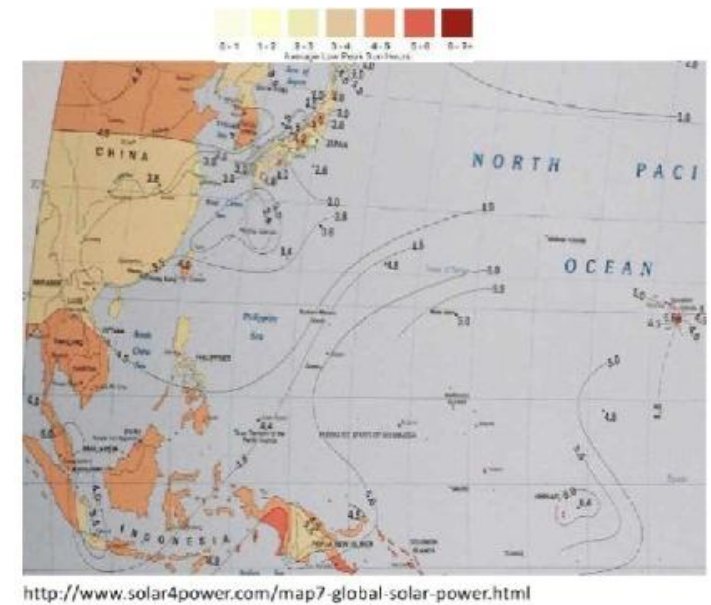

Gambar 10: Peta Total Penyinaran Optimum Per Hari Di Indonesia. 


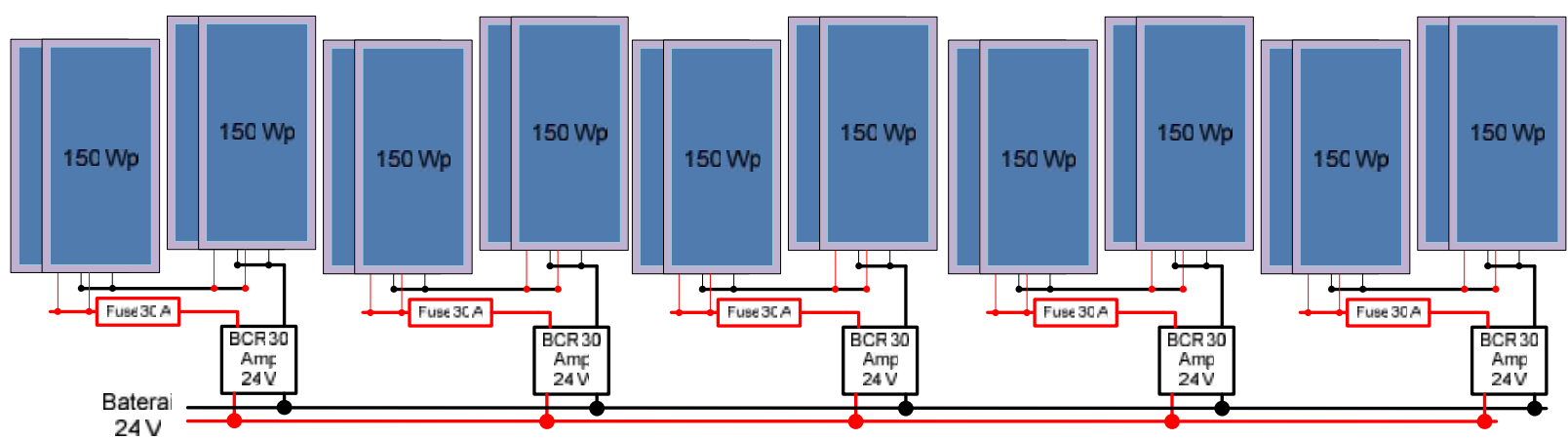

Gambar 11: Desain Konfigurasi Elektrikal Fotovoltaik.

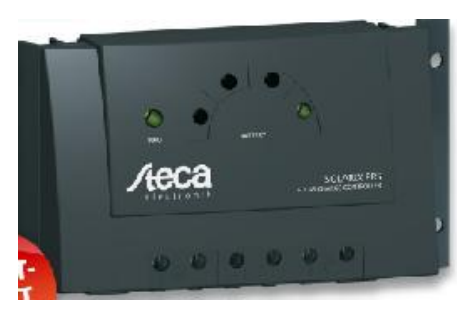

a)

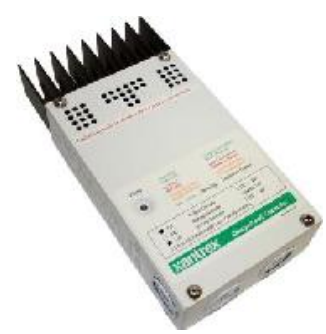

b)
Gambar 12. Produk BCR, a) BCR 30 A Untuk Sistem Pembangkit Rumahan, b) BCR 60 A Untuk Sistem PLTS Besar.

Untuk menghemat luas lahan yang dibutuhkan keseluruhan unit, modul fotovoltaik harus dipasang di atas/atap unit pengolahan air. Untuk konstruksi kerangka modul dapat menyesuaikan dengan kondisi bangunan yang nantinnya digunakan untuk menempatkan unit pengolahan air. Gambar 13 merupakan contoh desain konstruksi modul fotovoltaik dengan jumlah 20 modul. Desain tersebut dapat ditempatkan di bagian atap bangunan sistem pengolahan air.

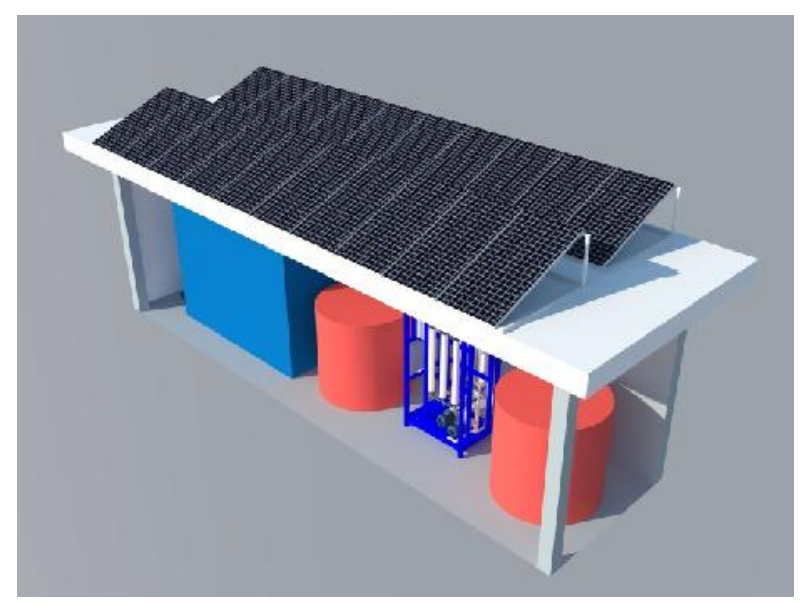

Gambar 13: Alternatif Desain Konstruksi Modul Fotovoltaik.
Yang perlu diperhatikan dalam konstruksi modul fotovoltaik ini adalah sudut kemiringan. Daya optimal akan diperoleh saat sinar matahari datang dari arah yang tegak lurus dengan modul fotovoltaik sehingga luas yang tersinari dalam kondisi optimal. Gambar 14 menunjukkan beberapa kejadian pengaruh kemiringan terhadap luasan sinar matahari yang ditangkap oleh modul fotovoltaik. Untuk konstruksi modul fotovoltaik yang dilengkapi dengan solar tracker, hal tersebut tidak terlalu masalah karena modul akan selalu diarahkan ke matahari namun untuk konstruksi modul yang fix kemiringan harus diatur sesuai dengan posisi geografis lokasi. Untuk menentukan sudut kemiringan paling optimal bisa dilakukan melalui kalkulator berbasis web yaitu: www.foresthillweather.com/PHP/Conversion/SunCalc 2.php.

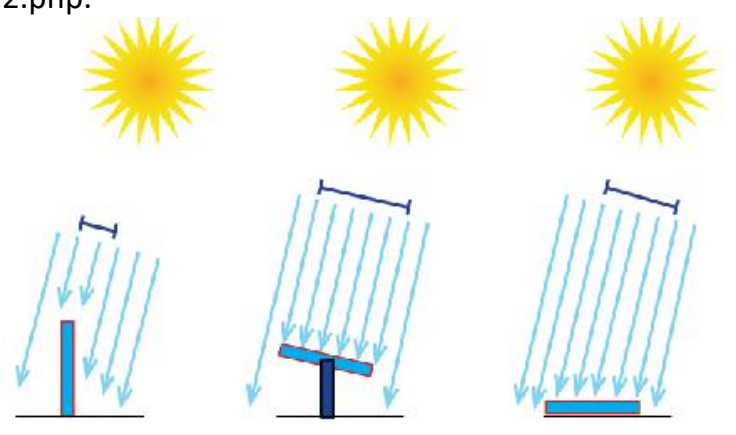

Gambar 14: Pengaruh Kemiringan Terhadap Luasan Sinar yang Diterima.

Baterai yang digunakan adalah baterai Deep Cycle. Pemilihan kapasitas penyimpanan baterai (Ah) dipilih berdasarkan pertimbangan berat dan dimensi. Referensi dimensi dan berat baterai diperoleh dari produsen baterai UPLUS ENERGY TECHNOLOGY CO., LTD. Berdasarkan pengalaman penulis, ukuran yang dipilih adalah 100 Ah 12 V dengan berat 30,4 kg dan dimensi $33 \mathrm{~cm} \times 17,3 \mathrm{~cm} \times 17,3 \mathrm{~cm}$. Berat tersebut dianggap ideal karena relatif mudah diangkat dan dipindahkan menggunakan tangan kosong. Dengan kebutuhan sebesar 1000 Ah maka baterai 100 Ah diperlukan berjumlah $\mathbf{1 0}$ buah. Jumlah baterai untuk sistem harus genap karena pada sistem ini akan dibuat 
tegangan kerja sebesar $24 \mathrm{~V}$ sehingga terdapat rangkaian seri dan paralel.

Ukuran daya inverter disesuaikan dengan kebutuhan daya keseluruhan unit. Untuk beban resistif seperti lampu, pemanas air, dan peralatan elektronik yang tidak menggunakan trafo, tidak memerlukan spesifikasi khusus yang perlu diperhatikan adalah kemampuan daya inverternya saja. Untuk beban reaktif seperti motor listrik, inverter yang digunakan harus memiliki output pure sine wave atau gelombang sinus murni agar daya dapat tersalur secara optimal dari inverter ke motor. Hal lain yang perlu diperhatikan adalah ukuran daya inverter harus lebih besar dibandingkan dengan kebutuhan daya. Hal tersebut dikarenakan beban reaktif seperti motor memiliki daya awal yang hampir 3 kali daya nominal dan memiliki faktor daya yang semakin menurun sehingga semakin bertambah hari pemakaian, nominal daya motor semakin naik. Untuk mengantisipasi permasalahan tersebut dan mengantisipasi faktor lain seperti penambahan peralatan maka disarankan inverter yang digunakan memiliki ukuran daya 2 hingga 3 kali dari kebutuhan. Kebutuhan daya pada sistem biofiltrasi-ultrafiltrasi adalah sebesar $\mathbf{1 2 0 0}$ watt sehingga ukuran inverter yang disarankan adalah $\mathbf{3 0 0 0}$ watt.

Gambar 15 pada lampiran menunjukkan skema rangkaian sistem kelistrikan sistem PLTS secara keseluruhan yang mencakup seluruh komponen utama.

Tabel 3 berikut ini adalah rangkuman kebutuhan komponen utama pembangkit tenaga surya untuk sistem pengolahan air minum biofiltrasi dan ultrafiltrasi kapasitas $50 \mathrm{m3} /$ hari.

Tabel 3: Kebutuhan Komponen PLTS.

\begin{tabular}{|c|c|c|c|}
\hline No. & Nama Komponen & Spesifikasi & Jumlah \\
\hline 1 & Modul Fotovoltaik & $150 \mathrm{Wp}$ & 20 \\
\hline 2 & Battery & $100 \mathrm{Ah} \mathrm{12} \mathrm{V}$ & 10 \\
\hline 3 & BCR & $30 \mathrm{~A} 24 \mathrm{~V}$ & 5 \\
\hline 4 & $\begin{array}{c}\text { Inverter (pure sine } \\
\text { wave) }\end{array}$ & $3000 \mathrm{~W}$ & 1 \\
\hline
\end{tabular}

\section{KESIMPULAN}

Dengan adanya alternativ teknologi pengolahan air minum menggunakan kombinasi teknologi biofiltrasi dan ultrafiltrasi yang memiliki banyak keunggulan jika dibandingkan dengan teknologi yang telah ada (pengolahan dengan bahan kimia) maka pada penelitian ini telah dihasilkan rancangan sistem Pembangkit Listrik Tenaga Surya (PLTS) yang dapat menyuplai kebutuhan pengolahan air tersebut selama 8 jam setiap hari sehingga menghasilkan volume air sebesar $50 \mathrm{~m}^{3}$ setiap harinya. Dengan kebutuhan daya sebesar 1300 watt, kebutuhan modul fotovoltaik yang dibutuhkan adalah sebanyak 20 buah dengan kapasitas masing-masing sebesar $150 \mathrm{Wp}$. Kebutuhan BCR untuk menyalurkan ke 20 modul fotovoltaik terebut adalah sebanyak 5 buah dengan kapasitas 30 A untuk tiap BCR. Konstruksi modul fotofoltaik pada perancangan ini direkomendasikan dipasang $\mathrm{di}$ atas bangunan pelindung sistem pengolahan air. Baterai yang dibutuhkan dalam sistem ini sebanyak 10 buah dengan kapasitas masing-masing sebesar 100 Ah (12 V). Dengan kapasitas penyimpanan tersebut, sistem ini dapat bekerja tanpa penyinaran matahari selama 8 jam. Inverter yang diperlukan untuk menyuplai beban induktif 1200 watt adalah sebesar 3000 watt dengan output gelombang sinus murni.

\section{DAFTAR PUSTAKA}

- A. Tamin M. Z.. 2010. Rencana Aksi Nasional Sistem Penyediaan Air Minum Untuk Kabupaten/Kota. Materi Presentasi. Direktur Pengembangan Air Minum Kementerian Pekerjaan Umum.

- PAMSIMAS. 2010. Jalur Cepat Mencapai MGDs Bersama PAMSIMAS. Buletin Cipta Karya Edisi 08/Tahun VIII/agustus 2010.

- Peraturan Menteri Pekerjaan Umum Republik Indonesia. 2013. Kebijakan Dan Strategi Nasional Pengembangan Sistem Penyediaan Air Minum. Permen PU no. 13/PRT/M/2013.

- Rahardjo I., Fitriana I.. 2005. Analisis Potensi Pembangkit Listrik Tenaga Surya di Indonesia. Strategi Penyediaan Listrik Nasional Dalam Rangka Mengantisipasi Pemanfaatan PLTU Batubara Skala Kecil, PLTN, Dan Pembangkit Energi Terbarukan. Publikasi IImiah ISBN 979-95999-5-4.

- Kolhe Mohanlal, Kolhe Sunita, Joshi J. C.. 2002. Economic Viability of Stand-Alone Solar Photovoltaic System in Comparison With DieselPowered System for India. Maulana Azad College of Technology. Energy Economic 24 (2002) 155165

- SELF. 2008. A Cost and Reliability Comparison Between Solar And Diesel Powered Pumps. Solar Electric Light Fund. self.org

- Ahmad Talal, Shankar Kalyanaraman, Fareeha Amjad, Lakshmi Subramanian. 2015. Solar vs Diesel: Where to draw the line for cell towers?. Center for Technology and Economic Development. New York University. ACM 978-14503-3163-0/15/05

- $\quad$ SuryaTek. Listrik Tenaga Surya (PV System) VS Gensets Diesel di daerah terpencil. Brosur Produk. PT. Suryatek Mulia Abadi.

- Said Nusa I. Widayat W. 2007. Pilot Plant Pengolahan Air Minum dengan Proses Biofiltrasi 
dan Ultrafiltrasi. Jurnal Air Indonesia. Pusat Teknologi Lingkungan BPPT. JAI Vol.4, No.1. ISSN 1441-318X

- $\quad$ Said N. I., Widayat W., Herlambang A., Machdar E. C.. 2002. Biofilter Untuk Pengolahan Limbah Industri Kecil Tekstil. Pusat Pengkajian dan Penerapan Teknologi Lingkungan BPPT.

- Nugroho R., Said Nusa I.. 2011. Perbaikan Kualitas Air Baku Perusahaan Air Minum (PAM) Dengan Biofiltrasi. Pusat Teknologi Lingkungan BPPT. JAI Vol.12, No.2. ISSN 1441-318X

- Said Nusa I.. 2009. Uji Kinerja Pengolahan Air Siap Minum Dengan Proses Biofiltrasi, Ultrafiltrasi dan Reverse Osmosis dengan Air Baku Air Sungai. Jurnal Air Indonesia. Pusat Teknologi Lingkungan BPPT. JAI Vol.5, No.2. ISSN 1441-318X

- Said Nusa I.. 2006. Aplikasi Proses Biofiltrasi dan Ultrafiltrasi Untuk Pengolahan Air Minum. Jurnal Air Indonesia. Pusat Teknologi Lingkungan BPPT. JAI Vol.2, No.1. ISSN 1441-318X

- Horan N.J.. 1990. Biological Wastewater Treatment Systems : Theory and Operation. University of Leeds, England. John Wiley \& Sons Ltd.

- HCP Pump. Professional Manufacturers of Submersible Pumps. Katalog Teknis. HCP Pump Manufacturer.,CO.LTD.

- Hiblow. Linear Air Pumps. Katalog Teknis. Hiblow Frane S.A.S.. http://pdf.directindustry.com/pdf/hiblow/hp-4060-80/19863-635051.html diakses pada tanggal 2 Februari 2017.

- CNP Pump. CHL, CHLF, CHLFT, Light Horizontal Multistage Centrifugal Pump Operation Manual. Dokumen Teknis. Nanfang Pump Industry Co.,Ltd.

- Pulsafeeder Series 100/150. Instruction Manual. Dokumen Teknis. Pulsafeeder, Inc. Europe. Units 12 and 13, Edison Road, Highfield Industrial Estates, Eastbourne, East Sussex BN23 6 PT.

- PPPPTK. 2008. Pengenalan Teknologi Tenaga Surya. Modul Pelatihan. Pusat Pengembangan dan Pemberdayaan Pendidikan dan Tenaga Kerja Kependidikan (PPPPTK) Bandung. ET-PLTS S-01-03

- R. Faisal A., Hawibowo S., Sunarno. 2013. Perancangan Sistem Otomasi Pengisian Baterai Dengan Energi Hybrid Tenaga Surya Sebagai Penyedia Daya Cadangan pada Peralatan Vital di Puskesmas Patuk 1 Gunungkidul. Jurusan Teknik Fisika UGM.
- P. Irawan Eko. 2011. Teknik Instalasi Pembangkit Listrik Tenaga Surya. Modul Pelatihan. Pusat Studi Energi UGM.

- Liem Ek Bien, Ishak Kasim, Wahyu Wibowo, Perancangan Sistem Hybrid Pembangkit Listrik Tenaga Surya dengan Jala-jala Listrik PLN Untuk Rumah Perkotaan. Laporan Penelitian, Jurusan Teknik Elektro, Fakultas Teknologi Industri, Universitas Trisakti, ISSN 1412-0372 Nomor 1 Volume 8 Halaman 37-56, Agustus 2008.

- K. Azhar. 2016. Materi Sesi Info Listrik Tenaga Surya. Modul Seminar. Politeknik Negeri Malang.

- Seai. 2009. Best Practice Guide Photovoltaics (PV). Sustainable Energy Authority of Ireland. DTI/Pub URN 06/1972

- Energy Market Authority. 2010. Handbook for Solar Photovoltaic (PV) Systems. Energy Market Authority Singapore. ISBN: 978-981-08-4462-2.

- Alasdair Miller \& Ben Lumby. 2012. Utility Scale Solar Power Plants - A Guide for Developers and Investors. Sgurr Energy Limited. International Finance Corporation

- GREENTEK. 2017. Solar Modules Technical Specifications of Solar PV Modules. Dokumen Teknis. Greentek India Pvt. Ltd. http://greentekindia.co.in/SolarModules.aspx

- Uplus New Technology Battery. 2015. Uplus, UPS Battery, US Series, UCP Series. Dokumen Teknis. Uplus New Technology Battery. UB-VA-UPS-201509

- Schneider Electric. 2015. C Series PWM Charge Controller. Dokumen Teknis. www.solar.schneider-electric.com. DS20150606

- Steca. 2016. Steca Solarix PRS, Solar Charger Controllers. Dokumen Teknis. www.steca.com/Steca-Solarix-PRS-en. V. 2016-1215 20:29

- Foresthill Weather. 2017. PV Array Tilt Angle Calculator. Aplikasi Web. www.foresthillweather.com/PHP/Conversion/Sun Calc2.php. Diakses Pada: 14 Februari 2017 


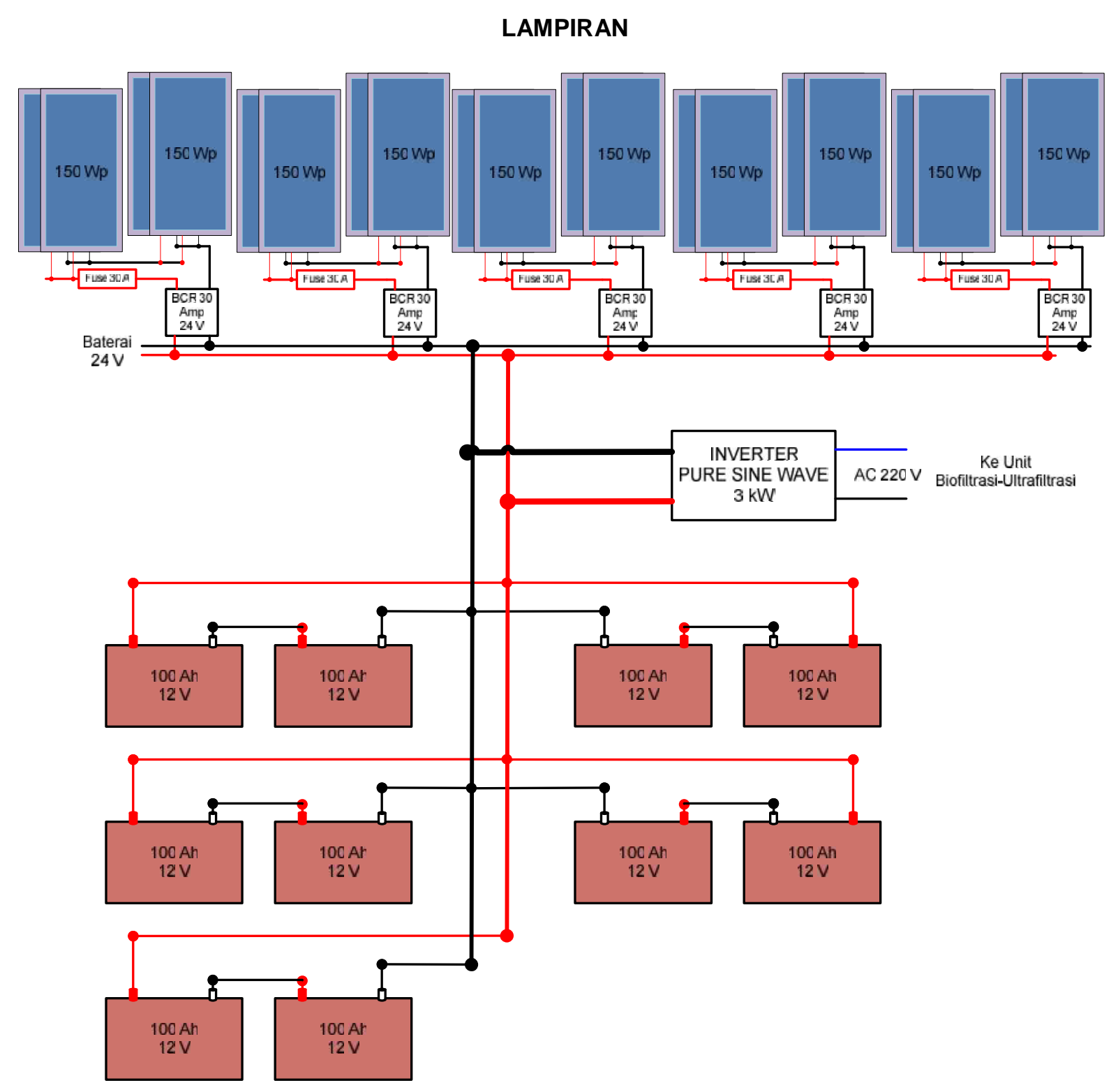

Gambar 15: Skema Kelistrikan Sistem PLTS. 